\title{
Kampen om idémessige forklaringer på japansk sikkerhetspolitikk: Kina i Japans identitetskonstrulksjon
}

Wrenn Yennie Lindgren ${ }^{1 \star} \&$ Petter Y. Lindgren ${ }^{2}$, ${ }^{1}$ M.Phil, M.A. Forsker, Norsk utenrikspolitisk institutt (NUPI); ${ }^{2}$ M.Phil, Samfunnsøkonom og fapanviter, ECON Consulting Group AS

I perioden 2010 til 2014 nådde konflikten om Senkakuøyene mellom Japan og Kina et klimaks. I denne artikkelen studerer vi den offisielle og dominerende japanske sikkerhetspolitiske diskursen vedrørende konflikten mellom Japan og Kina om Senkakuøyene i konfliktens klimaksperiode. Målet er å bidra til den relasjonelle litteraturen med en dyptpløyende casestudie av Kinas rolle som Den andre i japansk identitetskonstruksion i en kritisk periode i Øst-Asia. Casestudien er basert på lesning av bidrag fra og intervjuer med japanske myndigheter og eliter: politikere, akademikere, intellektuelle og andre meningsytrere i japansk offentlighet. Vi presenterer de mest sentrale identitetsmarkørene som benyttes til å kontrastere Japan mot Kina og hvordan disse kobles sammen til representasjoner av landene. Funnene fra casestudien støtter andre relasjonelle studier som foreslår at Japans identitet har vært i rask endring siden slutten av den kalde krigen. En av de viktigste endringene har vært at det $\mathrm{i}$ dag er mer legitimt å bruke militærmakt for avskrekkingsformål enn i etterkrigstiden i Japan.

Nøkkelord: Japan • Kina • identitet • sikkerhetspolitikk • Senkaku • Kinesisk-japanske relasjoner

The Senkaku islands dispute between Japan and China underwent a period of heightened tension between 2010-2014. In this article we study the official and dominant Japanese discourse on the Senkaku islands dispute between Japan and China during this period. The objective is to contribute to the relational studies literature with an in-depth case study of China's role as the 'other' in Japan's identity construction during a critical period in East Asia. The article's case study is based on a reading of texts from the Japanese government, elite politicians, academics, intellectuals and others engaged in Japan's public sector. We present the most central signs that are used to contrast Japan and China and discuss the connection between these signs and their role in Japanese identity

^Korrespondanse: Wrenn Yennie Lindgren, Norsk utenrikspolitisk institutt (NUPI). Email: wyl@nupi.no 
making. Our case study findings support those of other relational studies which suggest that Japan's identity has undergone significant change since the end of the Cold War. The emergence of a Japanese identity where the use of military power for deterrence purposes seems more legitimate than in the postwar period is one of the most important changes today.

Keywords: Japan - China - identity • security policy • Senkaku • Sino-Japanese relations

\section{Innledning}

Uenighetene mellom Japan og Kina om eierskapet til Diayou/Senkakuøyene ${ }^{1}$ og de omkringliggende havområder ${ }^{2}$ i Østkinahavet har potensielt store implikasjoner for stabiliteten i Øst-Asiaregionen. Landene i Øst-Asia er uenige i flere territorielle og maritime spørsmål, men Senkakuøykonflikten er den mest kritiske. Dupont og Baker (2014: 87) påpeker at «konflikten fortsetter å være betent og er etter vår mening den farligste i regionen, fordi den involverer Øst-Asias to største makter og risikerer å trekke inn USA som Japans allierte og ultimate sikkerhetsgarantist». Selv om USA ikke tar noens side i konflikten har Washington en rekke ganger uttalt at forsvaret av området ligger innenfor USAs forpliktelser i den amerikansk-japanske sikkerhetsalliansen. Eskaleringen av konflikten i 2010 og deretter i 2012 resulterte i forhøyet «sikkerhetisering» av konflikten, i den forstand at Senkakuøyenes rolle i kinesisk-japanske relasjoner ble gjenstand for nasjonal (og global) mediedekning, stor oppmerksomhet fra myndighetene på begge sider i konflikten og et økt akademisk fokus.

Senkakukonfliktens klimaks i perioden 2010 til 2014 utgiør altså et betydningsfullt, om enn understudert, felt for (re)produksjonen av japansk selvforståelse og synet på Kina. I denne artikkelen studerer vi derfor den offisielle og dominerende sikkerhetspolitiske diskursen vedrørende konflikten mellom Japan og Kina om Senkakuøyene i denne perioden. Målet er å bidra til den relasjonelle litteraturen med en dyptpløyende casestudie av konstruksjonen av Japans Selv og en av Japans signifikante Andre, Kina, i en kritisk periode i Øst-Asia. I kampen om fortolkningene som fant sted i denne perioden finner vi at representasjonen av Kina som et aggressivt, ikke-transparent diktatur settes opp mot forståelsen av Japan som et fredelig, transparent og rettsorientert demokrati. Idet disse representasjonene av Kina og Japan låses fast i den offisielle sikkerhetspolitiske diskursen, styrkes legitimeringen av bruk av militærmakt for avskrekkingsformål. Denne endringen i Japans sikkerhetspolitiske diskurs har allerede bidratt til en utvidelse av grensene for japansk

\footnotetext{
${ }^{1}$ Øygruppen refereres til som Diayou på kinesisk og Senkaku på japansk. I denne artikkelen brukes japanske kilder, og vi benytter i det følgende det japanske navnet. Dette betyr derimot ikke at vi tar noen lands parti i denne konflikten.

${ }^{2}$ Konflikten er både en territoriell og maritim konflikt, siden Kina og Japan har lagt fram krav om både havområdene omkring øyene i tillegg til krav om selve Senkakuøyene, se O’Shea (2015).
} 
sikkerhetspolitisk praksis: representasjonene av Kina og potensialet for militær konflikt spilte en sentral rolle $\mathrm{i}$ innføringen av en begrenset versjon av kollektiv sikkerhet i 2014 og 2015.

Øykonflikten eskalerte i 2010 da den japanske kystvakten krasjet med en kinesisk fiskebåt. Senkakukonflikten blusset opp igjen i 2012 i kjølvannet av at Tokyoguvernør Ishihara Shintarō proklamerte at han ville kjøpe noen av øyene. I dag øker uenigheten om eierskapet til Senkakuøyene potensialet for en større konflikt mellom Kina og Japan, Øst-Asias største økonomier og militærmakter. Casestudien er basert på kritisk lesning av bidrag fra japanske myndigheter og eliter: politikere, akademikere, intellektuelle og andre meningsytrere i japansk offentlighet. Studien inkluderer også en serie intervjuer med sentrale debattdeltakere i Tokyo i 2014.

Bidragene i den eksisterende akademiske litteraturen om Senkakukonflikten tar i bruk ulike perspektiver, men primært fokuseres det på faktorer og aktører som medvirket til konflikten, samt opptrapping og nedtrapping av konflikten. Gitt de overordnede implikasjonene av konflikten for kinesisk-japanske relasjoner har nyere studier fokusert på de politiske (Hughes 2009a; Togo 2014; Hook 2014; Midford 2015; Koga 2016), økonomiske (Koo 2009; Inoma 2011), historiske (Kawashima 2013; Manicom 2014), militære (Yamada 2010; Katsumata 2010; Ōmori 2011; Suzuki 2012) og juridiske (Suganuma 2000; Scoville 2015) aspektene. Selv om det nå finnes en omfattende litteratur om Senkakukonflikten, har mye av forskningen røtter i den realistiske tradisjonen. Noen få unntak har studert konflikten fra et konstruktivistisk perspektiv (Hagström 2012; Togo 2014; Pugliese 2015; Nakano 2016). ${ }^{3}$ Vårt bidrag er imidlertid det mest dyptpløyende i lesningen av hvordan Japans identitet blir (re-)konstruert vis-à-vis Kina som Japans Andre.

Realismens dominans i forskningen på Senkakukonflikten er påfallende, og da spesielt med hensyn til den japanske siden i konflikten. Når det gjelder Japan har nemlig realismen innenfor studiet av internasjonal politikk blitt kraftig utfordret av idémessige perspektiver. ${ }^{4}$ Strukturelle neorealisters forsøk på å predikere japansk sikkerhetspolitikk etter den kalde krigen (Waltz 1993; Layne 1993) ble imøtegått av normkonstruktivister som fremmet en diametralt forskjellig forståelse av hvordan Japan ville agere idet verden endret seg fra en bipolar til en unipolar verden (Berger 1993, 1996, 1998; Katzenstein og Okawara 1993; Katzenstein 1996). Mens de strukturelle neorealistene argumenterte for at Japan ville fjerne seg fra USA, øke militærbudsjettene, og kanskje til og med utvikle atomvåpen i kjølvannet av den kalde krigen, etablerte normkonstruktivistene et forskningsfelt som viste hvordan Japans «anti-militære kultur» og «fredelige kulturelle normer» la sterke begrensninger på sikkerhetspolitikken. I senere tid har nyklassiske realister nyansert de realistiske

\footnotetext{
${ }^{3}$ Alexander Bukh har benyttet relasjonell teori og metode i sine analyser av konflikten mellom Japan og Russland om Nordterritoriene $(2009 ; 2012)$ og i sin artikkel om Shimanefylket, Tokyo og territorialkonflikten om Takeshima/Dokdo (2015). Selv om Bukh har forsket på Japans territorialkonflikter har han ikke problematisert Senkakuøykonfliktens rolle i Japans identitetskonstruksjon.

${ }^{4}$ For en lengre diskusjon om litteraturen om japansk sikkerhetspolitikk, se Lindgren og Yennie Lindgren (2015).
} 
argumentene, gjennom å trekke veksler på interne forhold i Japan, samtidig som man vektlegger realistiske nøkkelbegreper som anarki, trusler og sikkerhetsbalanse (Heginbotham og Samuels 1998; Midford 2002; Lind 2004; Samuels 2007a, 2007b; Hughes 2009b). 1990-tallets normkonstruktivisme er også videreført i en større litteratur (Catalinac 2007; Ashizawa 2008; Oros 2008, 2014, 2015; Singh 2008, 2013; Rozman 2012, 2013).

Nylig har imidlertid en underskog av relasjonelle studier utfordret både den nyklassiske realismen og normkonstruktivismen i studiet av japansk sikkerhetspolitikk (Bukh 2009, 2010, 2012, 2015; Wirth 2009; Hagström og Jerdén 2014; Gustafsson 2015, 2016; Hagström 2015; Hagström \& Gustafsson 2015; Hagström \& Hanssen 2015, 2016; Suzuki 2015; Hanssen 2016). Selv om bruk av relasjonelle perspektiver inspirert av poststrukturell teori - utgjør en liten andel av forskningsfeltet om japansk utenrikspolitikk, vokser antallet slike studier raskt. Ifølge relasjonelle perspektiver produseres identitet av de diskursive praksisene som avgrenser det hjemlige og det internasjonale, det indre og det ytre, nasjonens Selv og Den Andre/De Andre (Campbell 1992; Doty 1993; Neumann 1996, 1998; Rumelili 2004; Hansen 2006). Mens normkonstruktivismen anfører et argument om sterk stabilitet i Japans sikkerhetsidentitet, viser de relasjonelle studiene snarere at det har vært en påfallende sterk endring i hvordan japanske eliter forstår Japan og dets nabolag, og således også hva slags sikkerhetspolitikk som oppfattes som riktig, smart og legitim. I Senkakukonflikten møter Japan en mer selvsikker nabo som etter årevis med sterk økonomisk og militær vekst ser ut til å ville ta en større stormaktsrolle i internasjonal politikk. Relasjonell teori er bedre utrustet til å trekke veksler på det internasjonale aspektet i Japans identitetskonstruksjon enn hva den hjemlig-orienterte normkonstruktivismen er.

Artikkelens struktur er som følger: først presenterer vi relasjonell teori og metode, samt en oppsummering av status i den relasjonelle litteraturen om Japans sikkerhetspolitikk i del 2. Dernest redegjør vi for konflikten mellom Japan og Kina om Senkakuøyene i del 3. I del 4 legger vi fram casestudiet av den dominerende sikkerhetspolitiske diskursen omkring Senkakukonflikten i Japan. Her diskuterer vi de mest sentrale identitetsmarkørene i denne diskursen, og hvordan disse markørene utgjør representasjoner av Japan og Kina. I siste del av artikkelen trekker vi konklusjoner. Et hovedfunn er at Senkakuøykonflikten fungerte som en katalysator for å styrke den sikkerhetspolitiske diskursen som anser militærmakt som legitimt for forsvar av Japans suverenitet.

\section{Relasjonell teori og metode og den relasjonelle litteraturen om Japan}

Relasjonelle studier, med inspirasjon fra poststrukturell teori, gjorde sitt inntog i studiet av internasjonal politikk (IP) på 1990-tallet (Campbell 1992; Doty 1993; Neumann 1996, 1998). Ved å trekke veksler på verkene til filosofer og sosialteoretikere som Michel Foucault, Julia Kristeva og Jaques Derrida har relasjonister i IP understreket at språk spiller en signifikant rolle i menneskelig samspill: det er gjennom språk at mening om verden genereres. Basert på denne meningsdannelsen 
handler og reagerer mennesker og derfor også større kollektiver som stater. Mening er ikke gitt a priori av den virkelige verden, men er konstruert intersubjektivt i det sosiale rommet mellom mennesker. Vi har således kun tilgang til verden - sosiale og fysiske objekter - gjennom språk. Mening er altså ikke gitt individuelt eller fysisk, men er (re)produsert i prosesser mellom mennesker i et kollektiv. Fordi språk blir sett på som 'ontologisk signifikant' av poststrukturalister (Hansen 2006: 18), i betydningen at forståelsen av verden og alle dens objekter er konstituert gjennom diskursive formasjoner av subjekter og identiteter, er poststrukturalistisk epistemologisk tankegang basert på ideen om at kunnskap om menneskers (og staters) atferd kan studeres gjennom analyser av identitetskonstruksjon.

Ifølge poststrukturalister er språk strukturert i diskurser, slik vi finner i Laclau og Mouffe's (1985) definisjoner av konseptene artikulasjon og diskurs. Artikulasjon refererer til praksiser (e.g. ytring, skrift, handling) som produserer og reproduserer meningsrelasjoner, setter sammen ord med andre ord og modifiserer meningen av disse, mens diskurs er 'den strukturerte totaliteten som resulterer fra artikulasjonspraksis’ (Laclau og Mouffe 1985: 105). Jørgensen og Phillip påpeker (2002: 50) at «enheter (diskurser, identiteter eller sosiale rom) alltid er etablert relasjonelt, i relasjon til noe de ikke er selv.» Dette poenget har klare referanser til Jacques Derridas argument om at meningsdannelse er basert på kontraster (juxtapositions); mening skapes kun når noe er kontrastert med det motsatte (Derrida 1976). Dette relasjonelle fokuset på inkludering og ekskludering vis-à-vis den Andre skiller relasjonister fra andre konstruktivistiske retninger innen studiet av IP. Et viktig poeng i denne sammenheng er at når ord eller hele totaliteter av språkpraksis - diskurser - er definert på en bestemt måte, vil andre tolkninger bli utelatt (Hansen 2006: 17). Når noen fortolkninger og representasjoner gjentas i det offentlige rom gang etter gang, etableres det hegemoniske diskurser som utelukker eller reduserer andre fortolkninger til utkanten av den offentlige debatt. ${ }^{5}$ Konflikten om Senkakuøyene bidro til å låse fast den dominerende sikkerhetspolitiske diskursen vi identifiserer $\mathrm{i}$ denne artikkelen til en hegemonisk diskurs.

Hansen (2006: 42) understreker at analyser av identitetskonstruksjon skal identifisere 'tegn' som bærer diskursen, fordi «mening og identitet er konstruert gjennom en serie av tegn som er koblet til hverandre for å konstituere relasjoner av likhet såvel som gjennom differensiering til andre serier av kontrasterende tegn.» I denne artikkelen benytter vi begrepet 'identitetsmarkører' i stedet for 'tegn', nettopp fordi vi ønsker å understreke begrepenes funksjon i konstitueringen av nasjoners identitet. Representasjoner av verden - gjennom koblinger av identitetsmarkører spiller en viktig rolle i differensieringsprosessene, og derfor også i konstitueringen av identitet, i det meningsdannelsen av Selvet og de(n) Andre trekker veksler på disse representasjonene. Relasjonister forsøker å belyse identitetsproduksjonens dynamikk

\footnotetext{
${ }^{5}$ Haugevik (2015) er et interessant relasjonelt bidrag om Storbritannia som Norges Andre. Mens det $\mathrm{i}$ denne artikkelen er et poeng at Kina tar en mer og mer framtredende plass som Japans Andre viser Haugevik at det er akkurat det motsatte som har skjedd i norsk sikkerhetspolitisk debatt: Storbritannia glimrer med sitt fravær i dagens norske diskurser.
} 
ved å analysere inkludering og ekskludering av flere Andre i relasjon til den nasjonale identiteten. Oppmerksomheten er rettet mot hvordan de sosiale grensene mellom menneskelige kollektiv dannes og opprettholdes (Neumann 1996: 166). Diskursive representasjoner av en nasjon og dets folk (Selvet) og deres allierte og fiender (Andre) har, ifølge relasjonelle tilnærminger i IP, implikasjoner for hvilken sikkerhetspolitikk som føres: konstitueringen av Selvet - landets identitet - forståes således som et mulighetsområde ikke bare for hva slags sikkerhetspolitikk som oppfattes som riktig, smart eller legitimt, men også som rammene for hva som er mulige og akseptable forslag og oppførsel i det politiske landskapet (Neumann 2008).

Det metodiske verktøyet samfunnsvitere har for å få tilgang til denne identitetskonstruksjonen er diskursanalyse (se Neumann 2001, 2008; Wæver 2002; Dunn \& Neumann 2016). Diskursanalyse har som mål å identifisere sentrale identitetsmarkører i diskursene man studerer og vie oppmerksomhet til det relasjonelle forholdet mellom slike markører og deres kontraster: det er nettopp gjennom koblingene og differensieringene at konstitueringen av identitetene blir (re)produsert.

Hansen (2006) tilbyr kanskje det mest strukturerte forslaget for forskningsdesign innenfor relasjonell litteratur. Hun argumenterer for at enhver diskursanalyse må besvare fire spørsmål: 1) hvilke(t) Selv skal studeres?, 2) hvilken tidsperiode skal undersøkes?, 3) hvilke(n) sak(er) skal en inkludere?, og 4) hvilke(n) agent(er) vil man studere? I vårt tilfelle kan forskningsdesignet formuleres slik: vi studerer (1) Japan (2) i perioden 2010-2014 (3) omhandlende Senkakuøykonflikten og (4) myndigheter, sentrale politikere, byråkrater og akademikere som alle støtter den offisielle diskursen.

I Japans tilfelle har det blitt undersøkt en rekke ulike Andre. Av åpenbar interesse for studiet av IP er studier av andre stater og regioner som Japan forholder seg til: USA (Suzuki 2015), Kina (Suzuki 2015; Gustafsson 2015; Gustafsson 2016), Sør-Korea (Tamaki 2010; Bukh 2015), Russland (Bukh 2009, 2010, 2012), Nord-Korea (Hagström \& Hanssen 2015), og Asia (Tamaki 2015). Men den Andre kan også være grupper innad i Japan, det være seg burakumin (Japans underkaste), koreanere, Ainu (urbefolkning nord i Japan), Okinawaere, osv. (MorrisSuzuki 1998, 2006; Oguma 1995, 2002). En interessant Andre er Japans egen fortid, som når Japan differensieres fra Japans militaristiske fortid (Gustafsson 2015), eller Japans 'pasifistiske' etterkrigstid (Hagström \& Hanssen 2015; Hanssen 2016).

Et knippe sentrale relasjonelle studier motiverer vår casestudie. I et av de mer spenstige bidragene i litteraturen argumenterer Hagström \& Hanssen (2016) for at det er stor forskjell mellom artikulasjonen av Japans identitet i 1972 og 2009-2012. De finner at nøkkelidentitetsmarkøren «fredelig» konstituerte Japans identitet i begge periodene, men at innholdet $\mathrm{i}$ identiteten hadde endret seg fra at Japan var en fredsstat kontrastert først og fremst mot sin egen militaristiske fortid til en fredelig nasjon omgitt av et usikkert nabolag der Kina utgjorde den primære Andre. De mener derfor at endringen i hvordan Japan konstitueres gjennom differensiering, først mot sin egen fortid som militaristisk regime og deretter mot Kina, har økt 
spillerommet for japanske konservative til å endre sikkerhetspolitikken mot styrking av militærkapasiteten. Suzuki (2015) har utfylt denne endringen i konstruksjonen av japansk sikkerhetspolitisk identitet ved å påpeke at mens det i Japan var vanlig at Kina tidligere ble sett på som et offer for japansk imperialisme, er forholdet nå blitt snudd opp ned: Kina blir nå konstruert som den aggressive aktøren i Øst-Asia. Suzuki finner at Japans identitet blir konstruert som overlegent Kina, i det Kina blir forstått som egenrådig, irrasjonell og arrogant, men at Japans suverenitet er truet av Kina. Denne utviklingen i hvordan Kina blir forstått i Japan leder Suzuki til å konkludere med at det er større rom for politisering av kinesisk-japanske relasjoner $\mathrm{i}$ dagens Japan enn tidligere.

Foruten Kina er Nord-Korea en sterkt tilstedeværende Andre i japanske sikkerhetspolitiske diskurser. Med sitt atomvåpenprogram, missilutskytninger og sitt autoritære regime, har Nord-Korea framstått som en av de viktigste truslene mot fred i den østasiatiske regionen. I Japan har imidlertid Nord-Koreas kidnapping av japanske statsborgere på 1970- og 1980-tallet dominert den sikkerhetspolitiske diskursen over lang tid. Da Kim Jong-Il i 2002 fastslo at de ubekreftede ryktene om slik kidnapping faktisk hadde funnet sted, ble Nord-Korea øyeblikkelig opphøyet og sikkerhetisert. Hagström og Hanssen (2015) har vist at kampen om forståelsen av Nord-Korea (og Japan) muliggjorde en glidning i Japans sikkerhetspoliske identitet ettersom tilhengerne av en hard linje mot Nord-Korea etterspurte en «normalisering» av Japan sikkerhetspolitikk. Ikke bare ble NordKorea konstruert som en «unormal» stat, men også Japans pasifistiske sikkerhetspolitikk ble tolket som «unormal»; den myke tilnærmingen til sikkerhetspolitikk i etterkrigstiden ble forstått som årsaken til at Japan ikke var i stand til å forsvare sine statsborgeres frihet.

I etterkrigstiden spilte USA en helt sentral rolle i japanske sikkerhetspolitiske diskurser; hele det utenrikspolitiske fokuset i Japan var under den kalde krigen rettet østover, mot den tidligere hovedfienden og nå viktigste allierte, både i positiv og negativ forstand. Å balansere mellom kritikken fra høyre (som ønsket uavhengighet og remilitarisering) og venstre (som stod for nøytralitet og pasifisme) ble en stor utfordring for de moderate konservative i Det liberaldemokratiske partiet. I dag er det kun hos det ytterste høyre og venstre at USA har rollen som den antagonistiske, negative Andre. Hos mer moderate stemmer framstår USA i stedet som ledestjernen i gruppen av (vestlige) internasjonale og utviklede samfunn.

Japans militaristiske og imperialistiske fortid utgjorde (og utgjør) en viktig Andre i Japans sikkerhetspolitiske diskurser. Japans oppmerksomhet var således hovedsakelig fokusert østover og innover (i rom) og bakover (i tid). Sentrale aktører i japansk politikk har i lang tid kritisert etterkrigstidens holdning til sikkerhetspolitikk som naiv og problematisk. Dette gjelder bl.a. statsministrene Hatoyama Ichirō (1954-56) og Kishi Nobosuke (1958-60) (se Pyle 1992). Det er imidlertid først på 1980-tallet spesielt med statsminister Nakasone Yasuhiro (1982-87) og i kjølvannet av det japanske «økonomiske mirakelet» - at man kan se konturene av en ny sentral Andre $\mathrm{i}$ japanske sikkerhetspolitisk diskurser: nemlig Japan i etterkrigsperioden. I dag framstår nettopp denne epoken ofte som en av de antagonistiske Andre i japanske 
debatter om sikkerhetspolitikk (se f.eks. Abe 2006; Hagström \& Hanssen 2016). Hanssen (2016) understreker at i etterkrigstiden ble det tabu å legitimere forsvarspolitikken med forsvar mot «hypotetiske fiender» - navngitte trusler nettopp fordi militariseringen forut for andre verdenskrig var fundert i analyser av hvordan utenlandske makter potensielt truet Japans sikkerhet. I stedet var den dominerende diskursen i etterkrigstiden basert på at Japan var unikt (i verdenshistorien) $\mathrm{i}$ at det slett ikke skulle oversette sin økonomiske status til tilsvarende militære kapasiteter. Sett i lys av hvordan Abe-regjeringen trakk fram Senkakuøyene som et potensielt tilfelle hvor Japan hadde behov for innføring av kollektiv sikkerhet med sine allierte i 2014, er det klart at diskursen om Senkakuøykonflikten har bidratt til å endre den sikkerhetspolitiske praksisen i Japan.

Relasjonelle studier har altså introdusert et fokus på Japans identitetskonstruksjon gjennom differensiering fra multiple Andre, både romlige og tidsmessige Andre. Spesielt viktig i så måte er Kina og Nord-Korea, men også USA og Japans egen fortid er identifisert som sentrale Andre i konstruksjonen av Japans nasjonale identitet. Studiene har også vist at det har funnet sted en endring i Japans identitet i perioden siden andre verdenskrig. De peker på at selv om «Japan som fredelig» fortsatt spiller en sentral rolle i Japans selvforståelse, har innholdet i «fredelig» endret seg. Det gir et større rom for sikkerhetspolitisk reorientering, slik for eksempel Abe-regjeringens innføring av en begrenset form for kollektivt selvforsvar i 2014/2015 signaliserer.

\section{Senkakukonflikten - territorielle og maritime krav}

Senkakuøyene er lokalisert i Østkinahavet, omtrent 120 nautiske mil sørvest for Okinawa og 120 nautiske mil øst for Fujianprovinsen i Kina. Nærheten både til det kinesiske fastlandet, Taiwan og Japans sørligste øyer bidrar til at Senkakuøyene er innenfor alle landenes krav om suverenitet og således del av et maritimt tvistemål. Den maritime konflikten tok til i kjølvannet av en geofysisk undersøkelse i 1968 som slo fast at det var stort potensiale for utvinning av petroleumsressurser i Østkinahavet. Allerede i 1969 krevde Taiwan suverenitet over øyene og tilgrensende havområder, mens Kina fulgte opp med slike krav i 1971. Når det gjelder de spesifikke maritime kravene baserer Kina sine krav på argumenter om en naturlig forlengelse av sin kontinentalsokkel (som når helt til Okinawa), mens de japanske kravene har vært knyttet til medianlinjen mellom Kina og Japan (fram til 2011). Idag er Japans posisjon at Senkakuøyene befinner seg innenfor de 200 nautiske milene som definerer Japans økonomiske sone (O'Shea 2015: 551-553).

Senkakuøyene er imidlertid også del av en egen territoriell konflikt, som har røtter i Øst-Asias moderne historie. Japan annekterte formelt øyene som en del av Ryūkyūkongedømmet i 1879 og øyene ble dernest inkorporert i Okinawafylket i 1895 - definert i Shimonosekiavtalen i kjølvannet av den kinesisk-japanske krigen i 1894-95. Japan påstår at øyene var terra nullius da de ble funnet og baserer sitt suverenitetskrav på dette kravet og på det faktum at landet siden har okkupert øyene. Som et resultat av San Fransisco-fredsavtalen i 1951 ble øyene overført til USAs militæradministrasjon i 1953. I 1972 ble øyene returnert til Japan - i 
reversjonsavtalen om Okinawa. Japan har administrert øyene siden 1972, men har begrenset utviklingen av øyene og har ikke etablert militære installasjoner på øyene. Det japanske standpunktet har siden 1970-tallet vært at øyene er en integrert del av Japans territorium (koyū no ryōdo), og således at det derfor ikke eksisterer noen konflikt. Den kinesiske posisjonen har derimot vært at øyene ble ulovlig overtatt av Japan sent i det 19. århundre, og at Kina ønsker disse øyene tilbake.

Etter at Japan normaliserte relasionene med fastlands-Kina i 1972, trakk det samtidig tilbake anerkjennelsen av Taiwan som egen stat. Således ble (både det territorielle og det maritime) tvistemålet offisielt en sak mellom Beijing og Tokyo. I 1978 ble imidlertid tvistemålet mellom Kina og Japan skrinlagt - gjennom den kinesisk-japanske avtalen om fred og vennskap, samtidig som Deng Xiaoping tok over makten i Kina og det kinesiske lederskapet implementerte sin 'Åpen dør'politikk. Deng Xiaoping foreslo at det skulle være framtidige generasjoners oppgave å finne en løsning på Senkakukonflikten (Fravel 2010: 157). Først i 1992 ble Senkakuøyene tatt opp igjen som et tema i internasjonal politikk, etter at Kina spesifiserte sine krav om Senkakuøyene sammen med sine maritime krav (O'Shea 2015: 551). I de senere årene har en rekke hendelser relatert til Senkakuøyene eskalert konflikten til nye høyder. Først ut var en kollisjon mellom en kinesisk tråler og to japanske kystvaktfartøy i området omkring øyene sommeren 2010. I kjølvannet av kollisjonen kjølnet de diplomatiske relasjonene mellom Japan og Kina. Dernest avslørte daværende Tokyoguvernør Ishihara Shintarō ${ }^{6}$ sine planer om å kjøpe to av øyene fra de private eierne høsten 2012. Utsagnet resulterte i fordømmelse fra Kina. I et forsøk på å dempe konfliktnivået besluttet den sittende Nodaregjeringen at den japanske staten skulle kjøpe øyene i stedet. Dette bidro imidlertid til forverring av det allerede anspente forholdet. Det er fortsatt ikke enighet mellom Japan og Kina om eierskapet til øyene og de tilgrensende havområdene, et faktum som skader de bilaterale relasjonene mellom to av Øst-Asias stormakter.

Selv om grensekonflikter i Øst-Asia ofte involverer to stater og således påvirker bilaterale relasjoner, kan slike konflikter skade relasjonene til tredjepartsland. Den amerikansk-japanske alliansen, USAs viktigste i Asia, medfører at USA involveres. Dette giør at Senkakukonflikten i hovedsak er en trepartskonflikt. USAs strategiske reorientering mot Øst-Asia, eksplisitt uttalt fra 2009, har ført til en konsentrasjon av Washingtons diplomatiske, økonomiske og sikkerhetsmessige kapasiteter mot regionen. Foruten at Kina er skeptisk til økt amerikansk tilstedeværelse i Øst-Asia, oppfatter Beijing at denne reorienteringen gir rom for at Tokyo får oppføre seg mer aggressivt i den maritime sfæren (Ratner 2013). Kina oppfattes på sin side å ta i bruk en strategi der små skritt til sammen til slutt fører til at kinesiske krav framstår som en kjensgjerning (O'Rourke 2014: 13). Fra japansk side utgiør USAs tilstedeværelse i regionen og alliansen med Washington den viktigste pilaren i sikkerhetspolitikken. Ukrainakrisen har imidlertid ført til økt skepsis i Japan når det gjelder om USA faktisk er forpliktet til å beskytte Japans interesser i tilfelle landet blir utsatt

\footnotetext{
${ }^{6}$ Ishihara er en kjent japansk politiker og forfatter som tilhører det radikale, historierevisjonistiske, populistiske høyre i Japan, se Lindgren (2015).
} 
for bruk av militærmakt (Cooper \& Fackler 2014). At Washington kun responderte på Ukrainakrisen med å kreve sanksjoner, ble forstått som at man tilsidesatte Budapest-memorandumet, som garanterte Ukrainas integritet (Cooper \& Fackler 2014). Viktige deler av etablissementet i Tokyo er derfor ikke overbevist om at USA er villig til å risikere en konfrontasjon med Kina hvis det blir nødvendig i Østkinahavet, for eksempel hvis Kina forsøker å annektere Senkakuøyene. Den amerikanske posisjonen er svært viktig for de involverte på japansk og kinesisk side $\mathrm{i}$ konflikten. Enhver uttalelse og handling fra Washington får derfor full oppmerksomhet i sikkerhetspolitiske miljøer i Øst-Asia.

\section{Senkakukonflikten som katalysator i japansk identitet}

I denne delen foretar vi en diskursanalyse av sentrale japanske politiske tekster for å belyse konstitueringen av Japans identitet i debattene omkring Senkakuøykonflikten. Vi konsentrerer oss om å identifisere identitetsmarkørene i den dominante diskursen, fordi det er bærerne av denne diskursen som former japansk sikkerhetspolitikk. Når det gjelder kildene i studien har vi primært valgt ut offisielle dokumenter fra japanske myndigheter, og komplementert disse med støttende stemmer i byråkratiet og akademia (se Tabell 1). Fire identitetsmarkører viste seg å være svært sentrale i den dominerende sikkerhetspolitiske diskursen, nemlig a) demokrati/diktatur, b) transparent/ikke-transparent, c) lovoverholdende/ustyrlig, og d) fredelig/aggressiv. De tre sistnevnte markørene er koblet sammen med demokrati som nøkkeltegn. I det følgende diskuterer vi hvordan disse identitetsmarkørene kobles sammen til representasjoner av Kina og Japan i den dominerende japanske diskursen.

Tabell 1. Oversikt over intervjuer med sentrale deltagere i den dominerende diskursen

\begin{tabular}{lll}
\hline Intervju \# & \multicolumn{1}{c}{ Stilling og institusjonstilknytning } & Intervjutidspunkt \\
\hline Intervju 1 & Tidligere viseutenriksminister, Forskningssektor & Tokyo, April 2014 \\
Intervju 2 & Forskningsleder, Canon Institute of Global Studies (CIGS) & Tokyo, April 2014 \\
Intervju 3 & Forsker og tidligere byråkrat, The Tokyo Foundation (TF) & Tokyo, April 2014 \\
Intervju 4 & Forskere, National Institute of Defense Studies (NIDS) & Tokyo, April 2014 \\
\hline
\end{tabular}

\section{Demokrati/diktatur}

En identitetsmarkør i den dominerende diskursen involverer de respektive styreformene som Japan og Kina har valgt og hvordan denne regimebeslutningen konstrueres som bærende for det bilaterale forholdet mellom landene i Senkakuøykonflikten. Gitt dets militaristiske og imperialistiske fortid i perioden før og under andre verdenskrig, understreker den dominerende diskursen etableringen av en demokratisk orden i Japan i kjølvannet av slutten av andre verdenskrig. I nåtidens Japan blir derfor demokrati sett på som en udiskutabel og naturlig karakteristikk av den japanske staten og nasjonen. Meningsdannelsen av Japan som et demokratisk samfunn blir kontinuerlig konstruert gjennom dets kontrast hos Japans viktigste 
nabo, nemlig Kina som diktatur (Suzuki 2015: 13; Hagström 2015: 132-133; Pugliese 2016: 53).

Selv om diskursdeltakerne villig, og regelmessig, innrømmer Kinas posisjon både økonomisk og militært, kritiserer de ofte Kinas regimeform og peker på Japan som et demokrati som en tydelig fordel (Ministry of Foreign Affairs (MOFA) 2013b; Kantei 2014; Intervju 3; Intervju 4). Statsminister Abe Shinzō uttrykte i en tale i Diet (det japanske parlamentet) i 2014 at visse verdier, inklusive prinsippet om demokrati, blir sett på som fundamentale og muliggiørende for samarbeid for Japan:

En demokratisk atmosfære fører til at folks potensiale blomstrer og bidrar til innovasjon. Jeg tror på at prinsippene om frihet og demokrati, menneskerettigheter og rettssikkerhet er fundamentet som vil bringe velstand til verden. Vi vil fordype vårt samarbeid med land som vi deler disse fundamentale verdiene med for at Japan og verden skal vokse i framtiden (Kantei 2014).

Diskursen rammer inn Kinas valg av styreform - kommunistisk diktatur - som en potensiell trussel og denne valgte statusen står i direkte motsigelse til Japans demokratiske tradisjon. For eksempel nevner en informant at variasjonen i meninger i offentlige debatter i Japan (som et demokrati) sammenlignet med den strenge sensuren i Kina (som diktatur) kan sees på som en type myk makt (soft power) (Intervju 2). Tilstedeværelsen av en slik variasjon i politiske meninger, også innenfor utenriks-/sikkerhetspolitikk blir sett på som en styrke for Japan. Dette synet er antydet i de direkte utsagnene og angrepene på Kinas kommunistregime og spesielt på dets sensur av regimekritikere. Kinas påståtte tilsidesettelse av menneskerettigheter er også benyttet som bevis på den iboende forskjellen mellom Japan og Kina og antyder en forståelse av Japans identitet som en drivkraft for demokratiske verdier, ytringsfrihet og menneskerettigheter (MOFA 2014b).

Kinas styreform er et eksempel på en inklusiv differensiering, idet den kan forståes som en i overveiende grad forsettlig og valgt form som potensielt kan reverseres hvis det blir ønskelig (Rumelili 2004). Mens andre naboer, for eksempel Sør-Korea, Taiwan og flere sørøstasiatiske land har sluttet seg til Japan i utviklingen mot et fullverdig demokrati, blir Kina (og Nord-Korea) differensiert som et diktatur, ved å koble nøkkelmarkøren diktatur med andre nedsettende markører som håndhevere av sensur og overtredelse av menneskerettigheter. Ved å lokalisere Kina på den ene siden av demokrati-/diktaturdikotomien reproduserer og bekrefter japanske offentlige dokumenter og sentrale stemmer i den dominerende diskursen Japans posisjon på den andre siden sammen med landets viktigste allierte, USA, og andre høyt ansette nasjoner i (Vest-)Europa. Gjennom denne konstitueringen av Japans identitet i demokrati-/diktaturdikotomien identifiserer deltakerne i diskursen Japan som et fullverdig medlem av den eksklusive klubben av demokratiske og fullt utviklede nasjoner.

\section{Transparent/ikke-transparent}

Stemmene i den dominerende diskursen er spesielt opptatt av transparens. De antyder at staters ærlighet om (militære) kapasiteter gir anledning for lovende 
internasjonale vennskap og gjensidige avtaler om å overholde lov og orden. Nettopp derfor er fraværet av åpenhet om kinesiske militærbudsjetter og -kapasiteter en konstant driver i produksjonen av Kina som en trussel i Japans identitetskonstruksjon. Sammen med Kinas høye militærutgifter og voksende militærkapasitet er ikketransparens en markør som truer Japans arbeid for regional fred og internasjonal orden.

Hvordan skal Japan møte en slik ikke-demokratisk og ikke-transparent nabo? Bærerne av den dominerende diskursen fremmer et syn på Kina som en potensiell trussel som Japan må utstyres for å svare på. Spesielt blir Kinas bemerkelsesverdige økning i militærutgifter og dets påståtte fravær av en omfattende og transparent strategi under dets ekspansjon sett på som farlig og truende (Ri 2012; Kitaoka i Kallendar-Umezu 2014; MOFA 2014d: 11).

Gjennom understrekingen av Kinas mangel på transparens reproduserer den dominerende diskursen et Japan som er transparent. Forfatterne av Utenriksdepartementets 2011 Diplomatic Bluebook reflekterer både over Japans samarbeid med andre transparente land og Kinas fravær av transparens:

Japan arbeider sammen med USA og andre bekymrede stater for å dele og utvikle reglene som kreves for regionalt samarbeid, fordi det er viktig at hvert land observerer handel, maritime og andre felles internasjonale regler, og øke gjennomsiktigheten og forutsigbarheten av dets [hvert lands] atferd for å opprettholde regional stabilitet og vekst ... På samme tid er Kinas militæroppbygging uten tilstrekkelig transparens, og dets økning i maritime aktiviteter er temaer for bekymring. Japan vil oppmuntre Kina til å spille en mer passende rolle som et ansvarlig medlem i det internasjonale samfunnet med økt transparens (MOFA 2011: 9-10).

To år senere, i en tale til Diet i 2013, kom utenriksminister Kishida Fumio med en lignende uttalelse i sin diskusjon av de tre pilarene i japansk utenrikspolitikk:

Fraværet av transparens i Kinas militæroppbygging og det økte nivået av maritim aktivitet $\mathrm{i}$ tilgrensende områder er kilder til bekymring for regionen ... Japan vil behandle situasjonen i Senkakuøyenes tilgrensede områder på en behersket måte med en stødig besluttsomhet for å snarrådig forsvare vårt territorium, sjøområder og luftrom. Gjennom vår kommunikasjon vil vi på det sterkeste be Kina om å begrense seg slik at situasjonen ikke eskalerer ytterligere (MOFA 2013c).

Ved å differensiere Kina som ikke-transparent, og ved å koble denne identitetsmarkøren til representasjonen av Kina som et diktatur reproduseres Japans identitet som transparent og demokratisk.

\section{Rettsorientert/ustyrlig}

Den tredje sentrale markøren i konstitueringen av Japans identitet i relasjon til Kina i den dominerende sikkerhetspolitiske diskursen om Senkakuøykonflikten er dikotomien rettsorientert versus ustyrlig. Denne representasjonen av Japan og dens Andre Kina - er, som transparensmarkøren, koblet til (re)produksjonen av Japan som et (fullverdig) demokrati og Kina som et diktatur. En informant utdypet synet på 
Kina og dets fravær av kunnskap om internasjonalt lovverk: «I Kina er det ikke noen grundig forståelse av internasjonal rett og noen offiserer kan gå for langt. Kina neglisjerer internasjonale lover, så det å bringe Senkakusaken til Den Internasjonale Domstolen (ICJ) er meningsløst» (Intervju 2). En annen informant advarte også mot den japanske entusiasmen om å bringe saken til ICJ, fordi «Kina aldri vil akseptere en kjennelse i favør av Japan» (Intervju 3).

Det er spesielt på det maritime området hvor Kinas manglende erfaring med maritime lover og reguleringer og dets tilsidesettelse av internasjonale standarder som blir kritisert gjentatte ganger. Som professor ved Japans Internasjonale Universitet, Kitaoka Shin'ichi, beskriver: Kina er 'temmelig ny på havet' og 'ikke vant med å adlyde veletablerte (maritime) regler', men 'det å være en maritim makt betyr å anerkjenne de ledsagende forpliktelsene' (i Kallendar Umezu 2014: 3).

Som for kontrasten demokrati/diktatur og transparent/ikke-transparent er markøren rettsorientert en inklusiv egenskap, i betydningen av at det er en karakteristikk nær sagt alle nasjoner kan tilegne seg (Rumelili 2004). Deltakerne i den dominerende japanske sikkerhetspolitiske diskursen nevner ofte hvordan Japan selv har utviklet seg til et transparent, rettsorientert demokrati fra et militaristisk regime i perioden før og under andre verdenskrig. Det er i tillegg viktig å være oppmerksom på at i konstitueringen av den japanske identiteten i koblingen mellom transparent, lovoverholdende og demokrati, faller Japan naturlig inn i gruppen av avanserte nasjoner i Nord-Amerika og Vest-Europa. Denne gruppen er konstruert som et internasjonalt samfunn av likesinnede politiske nasjoner.

Utenriksminister Kishida har understreket viktigheten av å motivere Kina til å utvikle seg fra sin posisjon som ustyrlig og vilkårlig til å bli et medlem av det rettsorienterte internasjonale samfunnet:

Vi må forsvare vårt territorium, hav og luftrom i områdene omkring Senkakuøyene. Historisk sett er dette politikken vi har gjennomført, og også i framtiden mener jeg at vi må opprettholde en besluttsom holdning for å behandle denne situasionen. I tillegg er frihet på de åpne hav og navigasjonsfrihet det internasjonale samfunns fundamentale verdier, og disse må forsvares. Jeg tror på viktigheten av å handle $\mathrm{i}$ samsvar med internasjonale lover, og også på viktigheten av å presse Kina til å handle i samsvar med lovene til hele det internasjonale samfunnet. Derfor mener jeg at det er viktig at vi stødig klargjør den juridiske basisen for våre egne handlinger, og at vi $\mathrm{i}$ framtiden opprettholder vår holdning om samsvar med internasjonale lover (MOFA 2014b).

Utenriksminister Kishidas tale er et ekko av en rekke uttalelser som statminister Abe og tidligere utenriksministre har hatt om Kina, Senkakuøykonflikten og nødvendigheten av å agere $\mathrm{i}$ henhold til internasjonale regler (MOFA 2012; Kantei 2013a; Abe 2014). I en artikkel publisert i juni 2014 angående Kina på det maritime området, under kronikksiden Project Syndicate, presenterte statsminister Abe tre 'veldig enkle, nesten selvinnlysende' prinsipper som stater burde følge når de forhandler om territorialkrav (Abe 2014: 1). For det første mente Abe at krav skal være avklart $\mathrm{i}$ henhold til internasjonal rett. For det andre skal ikke stater benytte makt eller tvang for å realisere sine mål. For det tredje skal stater søke å løse 
konflikter på en fredelig måte. Ifølge Abe må disse tre prinsippene framheves og overholdes i Asia og Stillehavsområdet. Flere bidragsytere til denne diskursen peker på hvordan Kina ikke overholder Abes foreslåtte normer og hvordan dette utgiør en utfordring for Japan.

Japans identitet som en lovoverholdende stat med lang erfaring med havet som rettsområde er implisert i differensieringen av Kina som en stat som åpenbart (for diskursdeltagerne) ikke overholder internasjonale standarder og som mangler erfaringen på det maritime området (Pugliese 2016: 53; Hagström 2015: 133). Igjen karakteriseres den Andre med en inklusiv (tilegnet) egenskap idet Kina velger å forfølge en slik tilnærming og landet blir derfor ikke rammet inn $i$ en iboende og uforanderlig karakteristikk. Den Nasjonale Sikkerhetsstrategien fra desember 2013 slår fast at:

Japan vil fortsette å oppmuntre Kina til å spille en ansvarlig og konstruktiv rolle $\mathrm{i}$ arbeidet med å skape regional fred, stabilitet og velstand, med å følge internasjonale normer for riktig atferd, samt med å forbedre åpenhet og transparens i landets økte militære kapasiteter gjennom dets økte militærbudsjetter. Som en del av dette arbeidet vil Japan, gjennom fortsatt fremming av forsvarssamarbeid, søke å presse på for forbedring av transparensen i Kinas militær- og sikkerhetspolitikk, og fremme tiltak slik som etablering av et rammeverk for å forhindre og avverge uventede situasjoner. Når det gjelder Kinas nylige forsøk på å endre status quo gjennom tvang basert på dets unike påstander i dets relasjoner i naboland, inkludert Japan, vil Japan i tillegg oppmuntre Kina til å utvise selvbeherskelse. Japan vil fortsette å besvare på en stødig men avkjølt måte, uten å eskalere situasjonen (Kantei 2013b: 26).

En informant uttrykte en lignende oppfatning, og forklarte at det er viktig for Japan å fortsette sin 'holdning med noen begrensninger og noen reaksjoner på Kinas ulovlige atferd' (Intervju 4).

\section{Fredelig/aggressiv}

Kina som en aggressor er en sentral markør i Japans differensiering av egen identitet fra Kina i den dominerende sikkerhetspolitiske diskursen. Japan blir i denne diskursen identifisert som en 'maritim nasjon' som vektlegger fredelig bruk av havet (MOD 2013b: 126). Det blir argumentert for at Kinas ekspansive utenrikspolitikk, og spesielt Kinas krav på Sør- og Øst-Kinahavene er eksempler på hvordan Kina har forvillet seg vekk fra en fredsfremmende praksis og forfulgt en voldelig og truende sikkerhetspolitikk. Utsagn som aktiverer fredelig/aggressiv-markøren dukker opp i en rekke dokumenter fra japanske myndigheter og i samtaler med informantene. Her blir Japan gjentatte ganger beskrevet som 'rolig', 'ansvarlig', 'sindig' og 'stødig' i sine handlinger overfor Senkakuøykonflikten og Kina blir anmodet om å følge Japans holdning og vedta en 'rolig respons' på konflikten (MOFA 2012; MOFA 2013a; MOFA 2013b; MOFA 2014b). Flere av informantene omtalte Kina som 'påståelig' og 'provoserende' (Intervju 1; Intervju 4).

Forfatterne av MOFAs Diplomatic Bluebook minner gang på gang både om at Japan setter relasjonen til Kina høyt (MOFA 2014d; 7, 8, 12) og at et militarisert 
Kina som handler unilateralt representerer en trussel mot et fredelig og stabilt regionalt miljø (MOFA 2014d: 4, 8, 12, 27). Oppsummeringen inneholder en kort oversikt over konfliktens historie basert på japanske myndigheters anskuelser, før dokumentet beskriver i detalj hvordan Kinas påstander og handlinger i 2013 (f. eks. etablering av kinesiske identifiseringssoner for luftforsvaret, inntrengen i havområdet og luftrommet rundt Senkakuøyene) er forsøk på å endre status quo i Øst-Kinahavet gjennom tvang (MOFA 2014d: 4, 8, 12). Forfatterne forklarer at Japan vil respondere på disse pågående forsøkene «stødig, men på en rolig måte basert på en besluttsomhet om å resolutt forsvare sitt territorium, sine hav og sitt luftrom»og Japan vil «anmode Kina om å ikke la situasjonen eskalere» (MOFA 2014d: 8, 12). Som for markøren rettsorientert/ustyrlig foreslår diskursdeltakerne at Kina kan - hvis det ønsker - lære av Japans eksempel. Dette impliserer en inklusiv (tilegnet) karakteristikk av Kinas identitet, og antyder at Japan blir forstått som å kunne utøve innflytelse på Kinas sosiale identitet gjennom å være en rolig og ansvarlig stat. I 2013-versjonen av Diplomatic Bluebook dekkes 2012-hendelsene, som inkluderer 40-årsjubileet for normaliseringen av de diplomatiske relasjonene mellom Japan og Kina, de japanske myndighetenes kjøp av tre av øyene, samt Kinas respons på oppkjøpet. Der blir følgende retorikk brukt:

Japan kan ikke, under noen omstendighet, tolerere Kinas oppførsel, som de baserer på sine egne krav. På samme tid vil Japan opprettholde sin rolige og stødige holdning i måten vi håndterer problemene med Senkakuøyene. Japan er klar til å fortsette sin kommunikasjon med Kina i den hensikt å dempe spenningen (MOFA 2013d: 11).

En annen argumentasjonsrekke fremstiller Kina som en 'irrasjonell' og 'unilateralorientert' Andre. Matsuda Yasuhiro, professor ved Tokyo Universitet, for eksempel, skriver om et Kina som «i stedet for å ty til fredelige metoder for å fremme sitt krav» bruker «vold og politisk press på Japan for tydeligvis å trekke ut innrømmelser fra Tokyo om Senkakuøykonflikten» (2012: 4). Matsuda foreslår at denne strategien blir benyttet fordi Kina ikke har selvtillit når det gjelder sine egne krav og fordi at man i Kina har en presedens for at «all strid med andre land burde klandres andre land» (2012: 5). Matsuda stempler slik atferd som «typisk for et diktatur», og anklager kinesiske myndigheter for å være "gissel for fantasier de selv har skapt og for et svært nasjonalistisk folk som tror på dem [fantasiene]» (2012: 5). Likeledes ble det kommunistiske partiets legitimitet framhevet som en driver for den kinesiske bruken av makt i konflikten i en diskusjon med en japansk forsvarsforsker:

Dette er helt og holdent et kinesisk valg [å fortsette eskaleringen av Senkakuøykonflikten] ... Provokasjonene har røtter i kinesisk innenrikspolitikk og kommunistpartiet trenger å opprettholde sin legitimitet ... Hvis kommunistpartiet tror at makt er siste utvei for å legitimere partiet så vil de benytte det (Intervju 4).

Kina som en aggressiv stat og Japan som en fredelig stat er en sentral differensiering som bidrar til å giøre Kina til Japans Andre (Hagström 2012: 293-294; Suzuki 2015: 13; Hagström 2015: 132-133; Hagström \& Hanssen 2016: 15). 
Et fredelig og demokratisk Japan er en mektig kobling i den dominerende sikkerhetspolitiske diskursen i debatten om Senkakuøykonflikten. Stemmene i diskursen er bekymret for at Kina kan avvike fra atferden man forventer av medlemmer av det internasjonale samfunnet, hvor konflikter antas å avgjøres i samsvar med internasjonal rett og gjennom politiske og diplomatiske virkemidler. Et viktig poeng er at selv om konstitueringen av Japan som en fredelig nasjon er en integrert del av den dominerende diskursen ber ikke deltakerne om at Japan skal avstå fra å bruke militærmakt i tilfeller der japansk territorium blir truet av kinesisk militærmakt. Snarere tvert imot: ifølge den dominerende diskursen må Japan være utstyrt militært for å forsvare sin suverenitet.

\section{Konklusjon}

Hendelsene relatert til Senkakuøyene mellom 2010 og 2014 medfører at denne perioden representerer en av de mest kritiske i kinesisk-japanske relasjoner i nyere tid. Nettopp derfor har Senkakuøykonflikten blitt et hovedtema i de japanske sikkerhetspolitiske debattene om Kinas framvekst som stormakt. Ved å ta utgangspunkt i relasjonell teori og metode har vi i denne artikkelen studert den dominerende japanske diskursen om Senkakuøykonflikten i denne perioden. Det er nettopp i møtet med Kina og forståelsen av den Andre at japanske eliter konstruerer meningen om hva Japan er og bør være. Artikkelen har kastet lys over hvilke markører, og forbindelsene dem imellom, som konstituerer Japans nåværende identitet.

Vår casestudie av differensieringsprosessene vis-à-vis Kina i Senkakuøykonflikten viser at Japan konstitueres langs dikotomiske identitetsmarkører hvor Japan konstrueres som den positive, mens Kina framstår som den negative Andre. Konstruksjonen av Japan som en fredelig, rettsorientert, transparent og demokratisk nasjon finner altså næring i Kina som en aggressiv, ustyrlig, ikke-transparent og diktatorisk stat. Den dominerende diskursens konstruksjon av Kina som et slikt land kaster lange skygger over hvilken sikkerhetspolitisk praksis som er ønskelig, tenkelig og legitim i Japan. Den sterke tilstedeværelsen av denne diskursen i japansk offentlighet $\mathrm{i}$ denne perioden har vært bidragsytende til at japanerne lempet på begrensningene for sikkerhetspolitikken ved å introdusere et prinsipp om kollektivt selvforsvar med sine allierte.

Senkakuøykonfliktens rolle i konstruksjonen av japansk identitet har vært underspilt i den relasjonelle litteraturen; denne artikkelen bøter derfor på dette gapet i litteraturen. I tillegg har det vært et poeng at i denne diskursen fungerer demokrati som nøkkeltegnet som andre markører - rettsorientert, fredelig og transparent - kobles til. Dette er et nytt funn, i og med at andre oppfatter fredelig til å være nøkkeltegnet i japanske sikkerhetspolitiske diskurser (Hagström \& Hanssen 2016). Både demokrati og fredelig har vært viktige markører i japanske sikkerhetsdiskurser siden slutten av andre verdenskrig. Det er imidlertid skjedd et skifte $\mathrm{i}$ hva disse markørene står for. I dag er disse markørene sentrale i å konstruere et demokratisk Japan som er i stand til å forsvare sin suverenitet, også militært, mot fiender av freden. Det er nå opp til videre studier å avdekke hvorvidt en lignende 
(re-)konstruksjon av Kina (og Japan) har funnet sted på andre felt enn Senkakuøykonflikten. Vi oppfordrer også framtidige forskere til å løfte blikket vekk fra den dominerende diskursen og utover til andre, alternative stemmer i de sikkerhetspolitiske debattene. Det kan være nyttig å undersøke hvorvidt og hvordan alternative, ikke-dominerende røster bidrar til å forme Japans sikkerhetspolitiske tenkning og praksis.

Mens Japans sikkerhetspolitiske debatter i lang tid var sterkt begrenset av konstruksjonen av Japans fortid som militaristisk (etterkrigstidens Andre) viser flere studier at de dominerende diskursene nå snarere konstruerer et Japan som har et nytt forhold til militærvesenet og en eventuell bruk av militærmakt. Her spiller Kina, Nord-Korea og tidvis også Japans pasifistiske etterkrigstid sentrale roller som Den andre nåtidens Japan differensieres mot. I et slikt diskursivt miljø virker remilitarisering og avskrekking gjennom militærmakt som mer rasjonelle virkemidler i sikkerhetspolitikken. Vår studie viser hvordan Kina konstrueres som en trussel mot stabiliteten i Østkinahavet spesielt og i hele regionen mer generelt. I tillegg er det et viktig element at det er usikkerhet omkring USAs kapasitet til å handle i tråd med sine sikkerhetsforpliktelser overfor Japan. Dette har bidratt til at argumenter om å forbedre Japans forsvar for å imøtekomme hendelser der freden er truet er styrket de senere årene. Vi har derfor argumentert for at den diskursive konstruksjonen av Senkakukonflikten og tolkningene som denne konflikten ble rammet inn i var bidragsytende for at Abe-regjeringen fikk flertall for at Japan skulle innføre en begrenset version av kollektiv sikkerhet i 2014 og 2015. I overensstemmelse med Hagström og Hanssens (2016) argument om at ønsket om å være en fredsnasjon faktisk kan implisere militarisering, konkluderer vi med at Japans sikkerhetsidentitet i dag i større grad enn tidligere muliggiør en aktiv og preventiv bruk av eget militærvesen for å opprettholde fred i nabolaget.

\section{Om artikkelen}

Vi er takknemlige for finansiell støtte fra Institutt for Forsvarsstudier (IFS), Norsk utenrikspolitisk institutt og Scandinavia-Japan Sasakawa Foundation. Vi vil også benytte anledningen til å takke Elana Wilson Rowe, Marc Lanteigne, Dick Stegewerns, Paul Midford, Jo Inge Bekkevold, Internasjonal Politikks redaktør Julie Wilhelmsen og to anonyme fagvurderere for kommentarer og tilbakemeldinger på tidligere utkast av denne artikkelen. Til slutt vil vi takke Naomi Yabe Magnussen for hjelp og støtte i forskningsprosessen.

\section{Litteraturliste}

Abe, S. (2006) Utsukushii kuni he [Mot et Vakkert Land]. Tokyo: Bunshun Shinsho.

Abe, S. (2014) «Securing the Rule of Law at Sea», Project Syndicate, 2. juni. Hentet fra: https://www.projectsyndicate.org/commentary/shinzo-abe-appeals-to-asia-pacific-leaders-to-adhere-to-agreed-principlesin-resolving-maritime-disputes Lesedato: 5. juni, 2014.

Ashizawa, K. (2008) «When Identity Matters: State Identity, Regional Institution Building, and Japanese Foreign Policy», International Studies Review 10(3): 571-598. 


\section{Wrenn Yennie Lindgren E Petter Y. Lindgren}

Berger, T. (1993) «From Sword to Chrysanthemum: Japan's Culture of Anti-Militarism», International Security 47(4): 119-150.

Berger, T. (1996) «Changing Norms of Defense and Security in Japan and Germany», i Peter J. Katzenstein (red.) The Culture of National Security: Norms and Identity in World Politics. New York, NY: Columbia University Press: 317-356.

Berger, T. (1998) Cultures of Antimilitarism: National Security in Germany and fapan. Baltimore, MD: Johns Hopkins University Press.

Bukh, Alexander (2009) «Identity, Foreign Policy and the 'Other': Japan's 'Russia'», European fournal of International Affairs 15(2): 319-345.

Bukh, A. (2010) «fapan's National Identity and Foreign Policy: Russia as fapan's “Other”». New York, NY: Routledge.

Bukh, A. (2012) "Constructing Japan's 'Northern Territories': Domestic Actors, Interests and the Symbolism of the Disputed Islands», International Relations of the Asia-Pacific 12(3): 483-509.

Bukh, A. (2015) «Shimane prefecture, Tokyo and the Territorial Dispute over Dokdo/Takeshima: Regional and National Identities in Japan», The Pacific Review 28(1): 47-70.

Campbell, D. (1992) Writing Security: United States Foreign Policy and the Politics of Identity, Minneapolis, MI: University of Minnesota Press.

Catalinac, A. (2007) «Identity Theory and Foreign Policy: Explaining Japan's Responses to the 1991 Gulf War and the 2003 U.S. War in Iraq», Politics Eo Policy 35(1): 58-100.

Cooper, H. \& M. Fackler (2014) «U.S. Response to Crimea Worries Japan's Leaders.» The New York Times, 5 april. http:/www.nytimes.com/2014/04/06/world/asia/us-response-to-crimea-worries-japanese-leaders.html Lesedato: 5. juni, 2014.

Derrida, J. (1976) Of Grammatology. Baltimore, MD: John Hopkins University Press.

Doty, R.L. (1993) «Foreign Policy as a Social Construction: A Post-Positivist Analysis of U.S. Counterinsurgency in the Philippines», International Studies Quarterly 37(3): 297-320.

Dunn, Kevin \& Iver B. Neumann (2016) Undertaking Discourse Analysis for Social Research. Ann Arbor: University of Michigan Press.

Dupont, A. \& C.G. Baker (2014) «East Asia's Maritime Disputes: Fishing in Troubled Waters», The Washington Quarterly, Spring, 79-98.

Fravel, Taylor M. (2010) «Explaining Stability in the Senkaku/Diaoyu Dispute», in Gerald Curtis, Ryosei Kokubun \& Jisi Wang (red.) Getting the Triangle Straight: Managing China-fapan-US Relations. Washington, DC: Brookings Institution Press.

Gustafsson, K. (2015) «Identity and Recognition: Remembering and Forgetting the Post-War in Sino-Japanese Relations», The Pacific Review 28(1): 117-138.

Gustafsson, K. (2016) «Routinised Recognition and Anxiety: Understanding the Deterioration in SinoJapanese Relations», Review of International Studies, FirstView Article: 1-21.

Hagström, L. \& B. Jerdén (2014) «East Asia's Power Shift: The Flaws and Hazards of the Debate and How to Avoid Them», Asian Perspective 38, 337-362.

Hagström, L. \& U. Hanssen (2015) "The North Korean Abduction Issue: Emotions, Securitization and the Reconstruction of Japanese Identity From 'Agressor to Victim and from Pacifist to Normal'», The Pacific Review 28(1): 71-93.

Hagström, L. \& U. Hanssen (2016) «War Is Peace: the Rearticulation of 'Peace' in Japan's China Discourse», Review of International Studies 42(2): 266-286.

Hagström, L. (2012) «Power Shift' in East Asia? A Critical Reappraisal of Narratives on the Diaoyu/Senkaku Islands Incident in 2010», The Chinese fournal of International Politics 5: 267-297.

Hagström, L. (2015) «The Sino-Japanese battle for soft power: pitfalls and promises», Global Affairs 1(2): $129-137$.

Hagström, L. \& K. Gustafsson (2015) «Japan and Identity Change: Why It Matters in International Relations», The Pacific Review 28(1): 1-22.

Hansen, L. (2006) Security as Practice: Discourse Analysis and the Bosnian War. London: Routledge.

Hanssen, U. (2016) «Japan's Temporal Others: How the Past has shaped Japanese Postwar Security Policy», mimeo. Utkast presentert ved NAJS konferansen, NTNU, Trondheim, 28-29 April.

Haugevik, K.M. (2015) «Ledestjernen som forsvant - Storbritannia i norsk utenrikspolitikk», Nytt Norsk Tidskrift 32(4): 341-351.

Heginbotham, E. \& R.J. Samuels (1998) «Mercantile Realism and Japanese Foreign Policy», International Security 22: 171-203. 


\section{Kampen om idémessige forklaringer på japansk sikkerhetspolitikk}

Hook, G.D. (2014) «Japan’s Risky Frontiers: Territorial Sovereignty and Governance of the Senkaku Islands», Fapanese Studies 34(1): 1-23.

Hughes, C.W. (2009a) «Japan's response to China's rise: regional engagement, global containment, dangers of collision», International Affairs 85: 837-856.

Hughes, C.W. (2009b) Fapan's Remilitarisation. New York: Routledge.

Inoma, A. (2011) Shigen kaihatsu no tachiba kara mita senkaku shotō mondai [Senkakusaken sett fra et ressursutviklingsperspektiv], Sekai, Mars: 36-44.

Jørgenson, M. \& L.J. Phillips (2002) Discourse Analysis as Theory and Method. London, Thousand Oaks and New Dehli: Sage Publications.

Kallendar-Umezu, P. (2014) «Interview: Shinichi Kitaoka», Defense Nerws, 7. juni. Hentet fra: http://www. defensenews.com/article/20140607/DEFREG/306070014/Interview-Shinichi-Kitaoka Lesedato: 20. juni, 2014.

Kantei (2013a) «Policy Speech by Prime Minister Shinzo Abe to the 183rd Session of the Diet», 28. februar. Hentet fra: http://japan.kantei.go.jp/96_abe/statement/201302/28siseuhousin_e.html Lesedato: 1. September, 2015.

Kantei (2013b) National Security Strategy of Fapan, 17. December 2013. Hentet fra: http://japan.kantei.go.jp/ 96_abe/documents/2013/_icsFiles/afieldfile/2013/12/17/NSS.pdf Lesedato: 20. September, 2015.

Kantei (2014) «Policy Speech by Prime Minister Shinzo Abe to the 186th Session of the Diet», 24. Januar; Hentet fra: http://japan.kantei.go.jp/96_abe/statement/201401/24siseihousin_e.html Lesedato: 7. September, 2015.

Katsumata, H. (2010) Yokushiryoku to fudansengen no wa zama de [Avskrekking og byrdelettelser er i en dårlig stilling], Chūō Kōron, December: 128-135.

Katzenstein, P.J. \& N. Okawara (1993) «Japan's National Security: Structures, Norms and Policies», International Security 17(4), 84-118.

Katzenstein, P.J. \& N. Okawara (2002) «Japan, Asian-Pacific Security, and the Case for Analytical Eclecticism», International Security 26(3): 153-185.

Katzenstein, P.J. (1996) Cultural Norms and National Security. Ithaca, NY: Cornell University Press.

Kawashima, S. (2013) "The Origins of the Senkaku/Diaoyu Islands Issue», Asia-Pacific Review 20(2): $122-145$.

Koga, K. (2016) «The rise of China and Japan's balancing strategy: critical junctures and policy shifts in the 2010s», Fournal of Contemporary China, DOI: 10.1080/10670564.2016.1160520

Koo, M.G. (2009) Island Disputes and Maritime Regime Building in East Asia. New York: Springer.

Laclau, E. \& C. Mouffe (1985) Hegemony and Socialist Strategy. Towards a Radical Democratic Practice. London: Verso.

Layne, C. (1993) «The Unipolar Illusion: Why New Great Powers Will Rise», International Security 17(4): 5-51.

Lind, J. M. (2004) «Pacifism or Passing the Buck?», International Security 29(1): 92-121.

Lindgren, P. \& W. Yennie Lindgren (2015) «Studiet av Japans Sikkerhetspolitikk: 3. Generasjons Forklaring på Stabilitet og Endring etter den Kalde Krigen», Internasjonal Politikk 15(3): 432-440.

Lindgren, P. Y. (2015) «Developing Japanese Populism Research through Readings of European Populist Radical Right Studies: Populism as an Ideological Concept, Classifications of Politicians and Explanations for Political Success», Fapanese Fournal of Political Science 16(3): 574-592.

Manicom, J. (2014) Bridging Troubled Waters: China, Fapan, and Maritime Order in the East China Sea. Washington, DC: Georgetown University Press.

Matsuda, Y. (2012) «China's Excessive Reactions to Senkakus Reflect Weakness of Its Territorial Claim», Asahi Shinbun, 12. Desember.

Midford, P. (2002) «The logic of reassurance and Japan's grand strategy», Security Studies 11(3): 1-43.

Midford, P. (2015) «Sino-Japanese Conflict and Reconciliation in the East China Sea», i Liao, T.F., K. Hara \& K. Wiegand (red.) The China-fapan Border Dispute, Surrey: Ashgate: 177-199.

MOD (2013a) «National Defense Program Guidelines for FY 2014 and Beyond», 17. Desember. Hentet fra: http://www.mod.go.jp/j/approach/agenda/guideline/2014/pdf/20131217_e2.pdf̄ Lesedato: 20. Mai, 2015.

MOD (2013b) «Security of the Oceans», in Defense of Japan. Hentet fra: http://www.mod.go.jp/e/publ/w_paper/ pdf/2013/29_Part2_Chapter2_Sec5.pdf Lesedato: 20. Oktober, 2014.

MOD (2013c) «Defense Program and Budget of Japan», desember. Hentet fra: http://www.mod.go.jp/e/d_ budget/pdf/260130.pdf Lesedato: 12. Mai, 2014.

MOFA (2011) Diplomatic Bluebook. Hentet fra: http://www.mofa.go.jp/policy/other/bluebook/2011/index.html Lesedato: 22. Oktober, 2014.

MOFA (2012) «Foreign Minister Gemba's Speech on Japan's Diplomacy in the Future at 'A Talk with Foreign Minister Gemba», 5. April. Hentet fra: http://www.mofa.go.jp/announce/jfpu/2012/04/0405-01.html Lesedato: 14. September, 2015. 


\section{Wrenn Yennie Lindgren $\mathcal{E}$ Petter Y. Lindgren}

MOFA (2013a) «Press Conference by Minister for Foreign Affairs Kishida», 8. Januar. Hentet fra: http://www. mofa.go.jp/announce/fm_press/2013/1/0108_01.html Lesedato: 5. Oktober, 2015.

MOFA (2013b) «Press Conference by the Assistant Press Secretary», 10. Januar. Hentet fra: http://www.mofa. go.jp/announce/press/2013/1/0110_01.html Lesedato: 5. Oktober, 2015.

MOFA (2013c) «Foreign Policy Speech by Minister of Foreign Affairs Kishida to the 183rd Session of the Diet», 28 February; Hentet fra: http:/www.mofa.go.jp/announce/fm/kishida/speech_130228.html Lesedato: 5. Oktober, 2015.

MOFA (2013d) Diplomatic Bluebook, 11. November. Hentet fra: http://www.mofa.go.jp/policy/page22e_ 000013.html Lesedato: 22. Oktober, 2014.

MOFA (2014a) «The Senkaku Islands», Pamphlet, mars. Hentet fra: http://www.mofa.go.jp/region/asia-paci/ senkaku/pdfs/senkaku_pamphlet.pdf Lesedato: 1. August, 2014.

MOFA (2014b) «Press Conference by Foreign Minister Fumio Kishida», 9. Mai. Hentet fra: http://www.mofa. go.jp/press/kaiken/kaiken4e_000068.html Lesedato: 5. Oktober, 2015.

MOFA (2014c) «Cabinet Decision on Development of Seamless Security Legislation to Ensure Japan's Survival and to Protect its People», 1. Juli. Hentet fra: http://www.mofa.go.jp/fp/nsp/page23e_000273. html Lesedato: 1. August, 2014.

MOFA (2014d) Diplomatic Bluebook. Hentet fra: http://www.mofa.go.jp/fp/pp/page22e_000566.html Lesedato: 22. Oktober, 2014.

Morris-Suzuki, T. (1998) Re-inventing Fapan. Time, Space, Nation. New York: Routledge.

Morris-Suzuki, T. (2006) «Defining the Boundaries of the Cold War Nation: 1950s Japan and Other Within», Fapanese Studies 26(3): 303-316.

Nakano, R. (2016) «The Sino-Japanese territorial dispute and threat perception in power transition», The Pacific Review 29(2): 165-186.

Neumann, I.B. (1996) «Self and Other in International Relations», European fournal of International Relations 2(2): $139-74$.

Neumann, I.B. (1998) The Uses of the Other: 'The East' in European Identity Formation. Minneapolis, MN: University of Minnesota Press.

Neumann, I.B. (2001) Mening, Materialitet, Makt: En Innføring i Diskursanalyse. Bergen: Fagbokforlaget.

Neumann, I.B. (2008) «Discourse Analysis», i Audie, K. \& D. Prakash (red.) Qualitative Methods in International Relations: a Pluralist Guide. London: Palgrave Macmillan (61-77).

Oguma, E. (1995) Tan'itsu minzoku shinwa no kigen: "Nihonjin" no jigazō no keifu [The Origin of the Myth of the Homogenous Nation: A Genealogy of "Japanese” Self-Images]. Tokyo: Shin'yōsha.

Oguma, E. (2008) "Minshu” to “aikoku”: sengo Nihon no nashonarizumu to kōkyōsei. [The "People" and "Patriotism": the Nationalism and Public Sphere of the Postwar Era]. Tokyo: Shin'yōsha.

Ōmori, Y. (2011) Botan hitotsu de kokka kimitsu wo baramakeru kyōfu [Frykten for at nasjonale hemmeligheter vil spres ved et tastetrykk]. Chūo Kōron, januar: 120-127.

Oros, A.L. (2008) Normalizing Fapan: Politics, Identity and the Evolution of Security Practice. Stanford, CA: Stanford University Press.

Oros, A.L. (2014) «Japan's Strategic Culture: Security Identity in a Fourth Modern Incarnation?», Contemporary Security Policy 35(2): 227-248.

Oros, A.L. (2015) «International and Domestic Challenges to Japan's Postwar Security Identity: 'Norm Constructivism' and Japan's New 'Proactive Pacifism'», The Pacific Review 28(1): 139-160.

O’Rourke, R. (2014) «Maritime Territorial and Exclusive Economic Zone (EEZ) Disputes Involving China: Issues for Congress», Congressional Research Service, 6 June.

O’Shea, P. (2015) «How Economic, Strategic, and Domestic Factors Shape Patterns of Conflict and Cooperation in the East China Sea Dispute», Asian Survey 55(3): 548-571.

Pugliese, G. (2015) «The China Challenge, Abe Shinzo's Realism and the Limits of Japanese Nationalism», SAIS Review of International Affairs 35(2): 45-55.

Pyle, K. (1992) The Fapanese Question. Power and Purpose in a New Era. Washington, DC: The AEI Press.

Ratner, E. (2013) «Rebalancing to Asia with an Insecure China», The Washington Quarterly 36(2): 21-38.

Ri, Tōki (2012) «Bïin wo mitara, jibun no tsuma da to shuchōsurukuni» [Når du ser en vakker person og insisterer på at det er din kone], Bungei Shunju, februar, 284-289.

Rozman, G. (2012) Introduction i G. Rozman (red.) East Asian National Identities: Common Roots and Chinese Exceptionalism. Woodrow Wilson Center Press and Stanford University Press, 1-16.

Rozman, G. (2013) «Introduction» i G. Rozman (red.) National Identities and Bilateral Relations: Widening Gaps in East Asia and Chinese Demonization of the United States. Woodrow Wilson Center Press and Stanford University Press, 1-15. 


\section{Kampen om idémessige forklaringer på japansk sikkerhetspolitikk}

Rumelili, B. (2004) «Constructing Identity and Relating to Difference: Understanding the EU's Mode of Differentiation», Review of International Studies 30(1): 27-47.

Samuels, R.J. (2007a) Securing Fapan. Tokyo's Grand Strategy and the Future of East Asia. Ithaca, NY: Cornell University Press.

Samuels, R.J. (2007b) «Securing Japan: The Current Discourse», fournal of Fapanese Studies 33(1): $125-152$.

Scoville, R.M. (2015) «Sovereignty over the Senkaku/Diaoyu Islands: A Guide to the Legal Debate», i Liao, T.F., K. Hara \& K. Wiegand (red.) The China-fapan Border Dispute. Surrey: Ashgate: 85-115.

Singh, B. (2008) «Japan's Security Policy: From a Peace State to an International State». The Pacific Review 21(3): 303-325.

Singh, B. (2013) Japan's Security Identity: From a Peace State to an International State. New York, NY: Routledge.

Suganuma, U. (2000) Sovereign Rights and Territorial Space in Sino-fapanese Relations: Irredentism and the Diaoyu/Senkaku Islands. Asian Interactions and Comparisons, Honolulu: Association for Asian Studies and University of Hawai'i Press.

Suzuki, Y. (2012) Mitsu shōmen sakusen wo tsuyoirareru nihon, nakaguchi no sekkin wo habame [Truet inn i en trefrontsstragi, Japan forhindrer medianframsteg], Chūō Kōron, October: 102-107.

Suzuki, S. (2015) «The Rise of the Chinese “Other” in Japan's Construction of Identity: Is China a Focal Point of Japanese Nationalism?», The Pacific Review 28(1): 95-116.

Tamaki, T. (2010) Deconstructing Fapan's Image of South Korea: Identity in Foreign Policy. New York: Palgrave Macmillan.

Tamaki, T. (2015) «The Persistence of Reified Asia as Reality in Japanese Foreign Policy Narratives», The Pacific Review 28(1): 23-45.

Togo, K. (2014) «Japan-China-US Relations and the Senkaku/Diaoyu Islands Dispute: Perspectives from International Relations Theory», Asian Perspective 38: 241-261.

Wæver, O. (2002) «Identity, Communities and Foreign policy: discourse analysis as foreign policy theory», i L. Hansen \& O. Wæver (red.), European Integration and National Identity: The Challenge of the Nordic States. London: Routledge, 20-50.

Waltz, K.N. (1993) «The Emerging Structure of International Politics», International Security 18(2): 44-79.

Wirth, C. (2009) «China, Japan, and East Asian Regional Cooperation: the Views of 'Self' and 'Other' From Beijing and Tokyo», International Relations of the Asia-Pacific 9(3): 469-496.

Yamada, Y. (2010) Senkaku jihen botsupatsu 'jizon jiei' no tatakai ga hajimaru [Senkakuhendelsens utbrudd, kampen om 'selv-eksisterende selvforsvar' begynner], Bungei Shunjū, November: 128-135. 